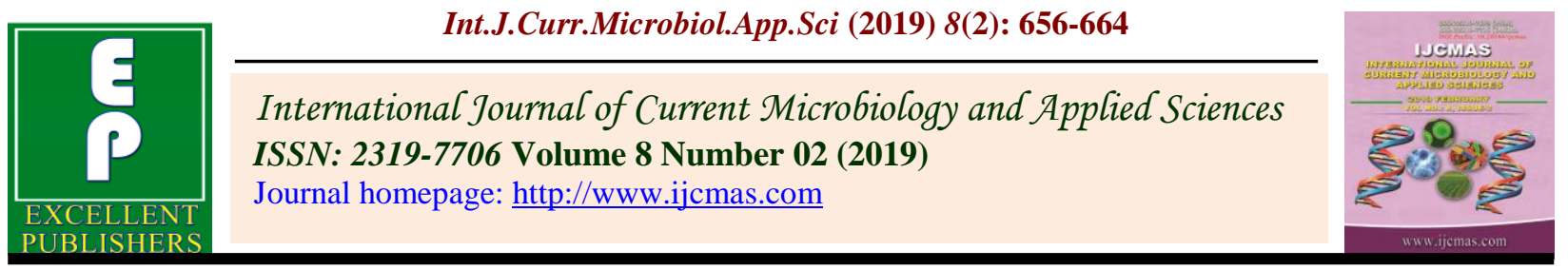

Original Research Article

https://doi.org/10.20546/ijcmas.2019.802.074

\title{
Investigation on Genetic Variability Parameters and Association of Traits in Horsegram (Macrotyloma uniflorum (Lam) Verdc.)
}

\author{
S. Priyanka, R. Sudhagar*, C. Vanniarajan and K. Ganesamurthy \\ Centre for Plant Breeding and Genetics, Tamil Nadu Agricultural University, \\ Coimbatore, Tamil Nadu, India \\ *Corresponding author
}

\section{A B S T R A C T}

\begin{tabular}{|l|}
\hline Key w or d s \\
Horsegram, \\
Quantitative traits, \\
Variability, \\
Correlation and \\
Path analyses \\
\hline Article Info \\
\hline Accepted: \\
07 January 2019 \\
Available Online: \\
10 February 2019 \\
\hline
\end{tabular}

\section{Introduction}

Horsegram (Macrotyloma uniflorum (Lam) Verdc.) is a hardy, drought tolerant legume crop adapted to wide range of Indian agricultural regimes. Horsegram is a promising nutritious crop; seeds contain relatively high lysine content compared to chickpea and red gram (Yadav, 2004). It is enriched with medicinal benefits which occupy an important role in Indian traditional medicine. Owing to these virtues, it is commonly known as poor man's pulse crop. Horsegram is also grown as a green manure
The extent of genetic variability and association between twelve quantitative traits in 252 horsegram genotypes was assessed. The study revealed the existence of wide range of variability in the genotypes. The difference between GCV and PCV was narrow which indicated less influence of environment on trait expression. High variability coupled with greater heritability and genetic advance was recorded in six traits viz., plant height, number of clusters per plant, number of primary branches, number of pods per plant, number of pods per cluster and single plant yield indicating better scope for improvement of these traits through adoption of simple selection techniques. Correlation and path analysis ealed that six traits viz., number of cluster per plant, plant height, pod length, number of plant, number of pods per cluster and number of seeds per pod had positive and diect effects with yield. Additionally these traits were also found to be influencing with yield indirectly through other yield attributing traits. Therefore, prioritized selection of these traits would be more promising for horsegram yield improvement.

crop because of its high potential towards atmospheric nitrogen immobilization. Generally, the crop is cultivated in marginal lands which led to low productivity and hence warrants focused scientific efforts like development of climatic resilient (Vijayakumar et al., 2016) varieties with yield potential. Breeding for high yielding varieties in horsegram would pave way to cater the nutritional security in developing countries.

Germplasm is serving as a genetic wealth of a nation as it possesses the pool of favorable genes. Tamil Nadu Agricultural University, 
India is maintaining a germplasm of 790 accessions. The knowledge on genetic variability of a germplasm collection/pre breeding stock is an essential prerequisite for initiating any crop improvement programme through plant breeding (Babu et al., 2012). Estimates of genetic parameter would offer better understanding on nature and magnitude of variability present in a population and thereby helpful in deciding appropriate selection techniques. Yield is a complex trait governed by polygenes; exhibiting low heritability too and hence direct selection for yield is offering limited scope. Hence selection based on components associated with yield would be more efficient and reliable (Kumar et al., 2013). Estimates of correlation coefficients, gives information on direction of trait association. The estimation of indirect relationship between traits is essential for targeted success in plant breeding (Dewey and Lu, 1959). A clear understanding on association of traits and its direct and indirect effects on yield would improve selection efficiency. Joshi et al., (2018) in a chickpea RIL population, Rakesh Gandi et al., (2018) in a blackgram segregating population and Narmada Varma et al., (2018) in a greengram germplasm had estimated the GCV, PCV, genetic advance and heritability of yield attributing traits and suggested the appropriate breeding methodology. Alle et al., (2015) estimated the extent of variability parameters and association between traits in horsegram. The present experiment was focused on estimating the nature and magnitude of variability; inheritance pattern of favorable traits; association between traits and importance of direct and indirect effect of traits on yield in a part of TNAU germplasm accession.

\section{Materials and Methods}

The experimental material comprises of 252 horsegram germplasm accessions of Tamil
Nadu Agricultural University (TNAU) which includes 250 accessions and two varieties viz., PAIYUR 2 (released by TNAU) and CRIDA1-18 R (released by Central Research Institute for Dryland Agriculture) (Table 1). The genotypes were sown in $4 \mathrm{~m}$ lengthened row with a spacing of $30 \mathrm{~cm} \times 10 \mathrm{~cm}$ during rabi season of 2017 at experimental farms of Department of Pulses, TNAU, Coimbatore. The accessions were raised in Randomized Block Design and replicated twice. Data was recorded on five randomly selected plants for 12 quantitative traits viz., days to $50 \%$ flowering, days to maturity, plant height $(\mathrm{cm})$, number of primary branches per plant, pod length $(\mathrm{cm})$, pod width $(\mathrm{cm})$, number of clusters per plant, number of pods per cluster, number of pods per plant, number of seeds per pod, 100 seed weight (g) and seed yield per plant $(\mathrm{g})$. Except days to flowering and maturity, other yield contributing traits were recorded at harvest. Computation of genotypic variance, phenotypic variance and genetic advance was done as per formula of Johnson et al., (1955a). Genotypic and phenotypic coefficient of variation (Burton, 1952), heritability in broad sense (Lush, 1940), correlation coefficient (Singh and Chaudhary, 1995) and path analysis (Dewey and $\mathrm{Lu}$, 1959) were estimated as per the procedure of the authors given in the parentheses. The statistical analyses were done using Indostat-version 7.1 software.

\section{Results and Discussion}

Horsegram, the underutilized but therapeutic and nutritionally potential fabaceae crop requires less or no water and sustains the livelihood of marginal and poor Indian farmers during rabi season. It requires attentive scientific intervention to enhance the yield potential and thereby to gratify the nutritional requirements of downtrodden farmers. Development of multiple stress tolerant; better yielding and quality 
possessing varieties is the major part of such intrusion. The probability of success in any breeding programme depends on the existence of wide range of variability for the trait concerned. Collection and conservation of germplasm offers a possible mean for restoration of genetic variability and also act as a reservoir for future breeding strategies. On the mission of germplasm conservation, TNAU is maintaining a total of 790 horsegram accessions. Of this totality, 252 accessions were utilized to study the magnitude of variability and correlation analyses. The analysis of variance (ANOVA) exhibited significant differences among genotypes for all 12 quantitative traits studied; indicated the existence of greater variability and offers some scope for bringing improvement in horsegram.

The estimates of genotypic (GCV) and phenotypic coefficient of variation (PCV), heritability (broad sense) and genetic advance (GA) were presented in table 2. The values of PCV and GCV values were categorized as low (below 10\%), moderate (11\%-20\%) and high (above 20\%) according to the scale given by Sivasubramanian and Menon, 1973. The traits studied in this experiment showed all the above three classes of GCV and PCV. Traits viz., single plant yield $(48.881 \%$ and $49.371 \%$ ) followed by number of pods per plant $(45.370 \%$ and $45.657 \%)$ recorded the highest GCV and PCV. Similar results were also noticed by Alle et al., (2015) and Vijayakumar et al., (2016) in horsegram. The lowest percent of GCV and PCV were recorded in days to maturity $(2.913 \%$ and $2.996 \%$ ) followed by days to $50 \%$ flowering (5.299\% and 5.374\%). Moderate GCV and PCV values were scored by pod length, pod width, number of seeds per pod and hundred seed weight. The PCV was found to be slightly higher than GCV in all traits studied indicating the importance of greater genetic variability with less influence of environment.
Hence selection based on phenotype will be more reliable in horsegram improvement. Akin suggestion was also opined by Latha et al., 2013.

Heritability $\left(\mathrm{h}^{2}\right)$ acts as a predictive measure for designing the selection procedure in a breeding programme. It provides information on heritable portion of observed effects. Classification of heritability into low (below $30 \%)$, medium (30\% - 60\%) and high (above $60 \%$ ) was suggested by Johnson et al., (1955a). All the characters involved in this study exhibited high heritability which ranged from 0.793 to 0.987 suggesting for adoption of simple selection technique on basis of phenotypic expression of trait since there is less influence of environment. Heritability estimates along with genetic advance provide a reliable measure for predicting the genetic gain under selection. High genetic advance as percent of mean (GAM) coupled with high heritability was observed for all the experimented traits except days to $50 \%$ flowering and days to maturity indicating the preponderance of additive gene action in expression of these traits. Hence, suggesting employment of simple selection techniques for improvement of these traits and would be more rewarding too. The trait viz., days to maturity exhibited low GAM with high heritability which signifies the importance of non-additive effects and the high heritability results due to favourable influence of environment. On a nutshell, high variability coupled with high heritability and genetic advance was observed for six traits viz., plant height, number of clusters per plant, number of primary branches, number of pods per plant, number of pods per cluster and single plant yield. Thus there is a great scope for improvement of these traits through selection.

The genotypic $\left(\mathrm{r}_{\mathrm{g}}\right)$ and phenotypic correlation coefficients $\left(r_{p}\right)$ among 12 quantitative traits were presented in table 3 . 
Table.1 List of horsegram germplasm accessions

\begin{tabular}{|c|c|c|}
\hline $\begin{array}{c}\text { No. of } \\
\text { genotypes }\end{array}$ & $\begin{array}{l}\text { Nature of } \\
\text { genotypes }\end{array}$ & Genotypes \\
\hline 250 & Accessions & 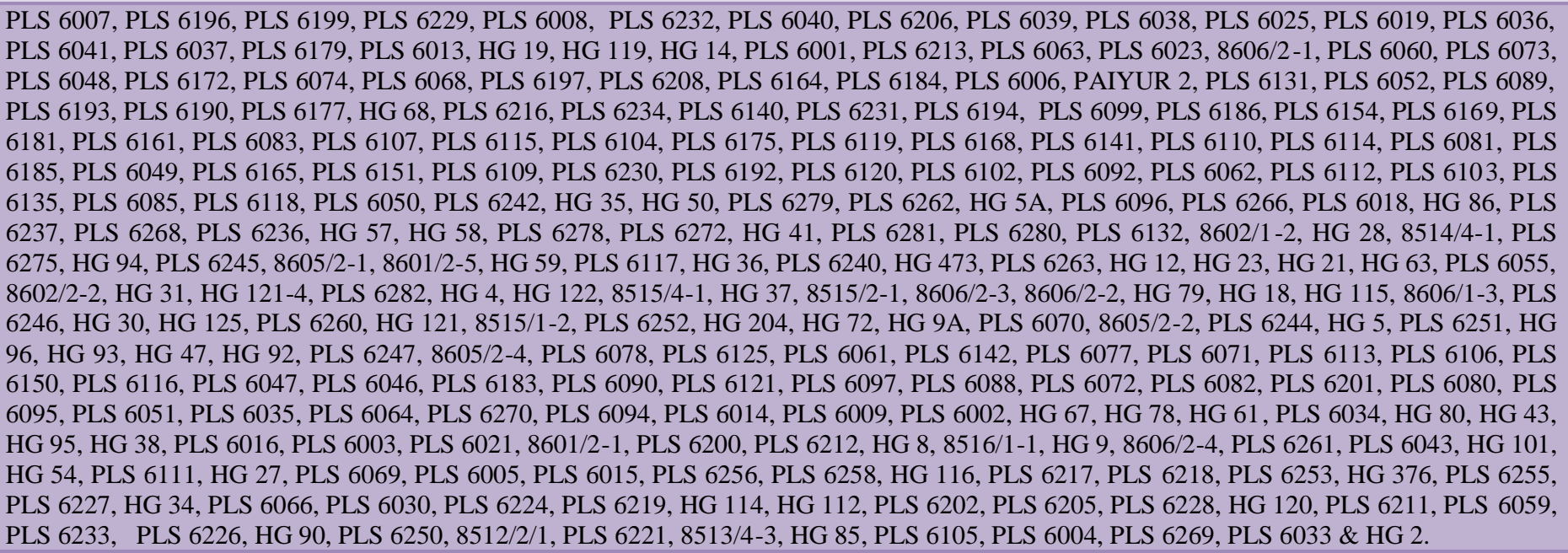 \\
\hline \multirow[t]{2}{*}{2} & \multirow{2}{*}{$\begin{array}{l}\text { Varieties in } \\
\text { cultivation }\end{array}$} & PAIYUR 2 \\
\hline & & CRIDA $1-18 \mathrm{R}$ \\
\hline
\end{tabular}

Table.2 Estimates of variability and heritability parameters

\begin{tabular}{|l|c|c|c|c|c|}
\hline \multicolumn{1}{|c|}{ Traits } & GCV & PCV & $\mathbf{h}^{\mathbf{2}}$ & GA & GAM \\
\hline Days to 50 \% flowering & 5.299 & 5.374 & 0.972 & 6.122 & 10.762 \\
\hline Days to maturity & 2.913 & 2.996 & 0.945 & 6.241 & 5.833 \\
\hline Plant height & 22.156 & 23.412 & 0.896 & 26.215 & 43.194 \\
\hline Pod length & 12.395 & 12.967 & 0.914 & 1.233 & 24.407 \\
\hline Pod width & 16.335 & 16.887 & 0.936 & 0.184 & 32.551 \\
\hline Number of clusters per plant & 31.526 & 32.016 & 0.970 & 29.035 & 63.947 \\
\hline Number of primary branches & 27.140 & 30.469 & 0.793 & 2.967 & 49.798 \\
\hline Number of pods per plant & 45.370 & 45.657 & 0.987 & 106.543 & 92.877 \\
\hline Number of pods per cluster & 29.779 & 30.144 & 0.976 & 1.516 & 60.602 \\
\hline Number of seeds per pod & 13.356 & 13.840 & 0.931 & 1.450 & 26.551 \\
\hline Hundred seed weight & 10.819 & 11.005 & 0.967 & 0.909 & 21.912 \\
\hline Single plant yield & 48.881 & 49.371 & 0.980 & 22.907 & 28.081 \\
\hline
\end{tabular}

GCV: Genotypic coefficients of variation, PCV: Phenotypic coefficients of variation, ECV: Environmental coefficients of variation, $\mathbf{h}^{2}$ : heritability (broad sense), GA: Genetic advance, GAM: Genetic advance as percent of mean 
Table.3 Estimates of genotypic and phenotypic correlation coefficients in horsegram accessions

\begin{tabular}{|c|c|c|c|c|c|c|c|c|c|c|c|c|c|}
\hline & & DFF & DTM & PH & PL & PW & NCP & NPB & NPP & NPC & NSP & HSW & SPY \\
\hline \multirow[t]{2}{*}{ DFF } & $\mathrm{G}$ & 1.0000 & $0.9873 * *$ & $-0.1289 *$ & -0.0215 & $-0.2168 * *$ & 0.0320 & 0.0378 & -0.0872 & $-0.1960 * *$ & $-0.1243 *$ & 0.0525 & -0.0760 \\
\hline & $\mathrm{P}$ & 1.0000 & $0.9519 * *$ & -0.1220 & -0.0180 & $-0.2073^{* *}$ & 0.0295 & 0.0319 & -0.0873 & $-0.1921 * *$ & -0.1186 & 0.0498 & -0.0758 \\
\hline \multirow[t]{2}{*}{ DTM } & G & & 1.0000 & $-0.1377 *$ & -0.0801 & $-0.1903 * *$ & -0.0183 & 0.0610 & $-0.1358^{*}$ & $-0.2119 * *$ & $-0.1473^{*}$ & 0.0998 & -0.1125 \\
\hline & $\mathrm{P}$ & & 1.0000 & $-0.1253 *$ & -0.0722 & $-0.1781 * *$ & -0.0219 & 0.0380 & $-0.1321 *$ & $-0.2037 * *$ & $-0.1403 *$ & 0.0959 & -0.1108 \\
\hline \multirow[t]{2}{*}{ PH } & $\mathrm{G}$ & & & 1.0000 & 0.1153 & $-0.1594 *$ & $0.2886 * *$ & $0.2492 * *$ & $0.3740 * *$ & $0.2939 * *$ & 0.0552 & $-0.2042 * *$ & $0.3266^{* *}$ \\
\hline & $\mathrm{P}$ & & & 1.0000 & 0.1091 & $-0.1407 *$ & $0.2688 * *$ & $0.2006 * *$ & $0.3549 * *$ & $0.2809 * *$ & 0.0501 & $-0.1736^{* *}$ & $0.3154 * *$ \\
\hline \multirow[t]{2}{*}{ PL } & G & & & & 1.0000 & $-0.4105^{* *}$ & $0.2742 * *$ & $-0.2690 * *$ & $0.5096^{* *}$ & $0.4573 * *$ & $0.6334 * *$ & $-0.3606 * *$ & $0.5659 * *$ \\
\hline & $\mathrm{P}$ & & & & 1.0000 & $-0.3606 * *$ & $0.2570 * *$ & $-0.2201 * *$ & $0.4760 * *$ & $0.4222 * *$ & $0.5902 * *$ & $-0.3304 * *$ & $0.5332 * *$ \\
\hline \multirow[t]{2}{*}{ PW } & G & & & & & 1.0000 & -0.1216 & $0.2622 * *$ & $-0.1813^{* *}$ & -0.0885 & -0.0190 & $0.3103 * *$ & $-0.1457 *$ \\
\hline & $\mathrm{P}$ & & & & & 1.0000 & -0.1160 & $0.2359 * *$ & $-0.1732 * *$ & -0.0865 & -0.0107 & $0.2963 * *$ & $-0.1356^{*}$ \\
\hline \multirow[t]{2}{*}{ NCP } & G & & & & & & 1.0000 & $0.2173 * *$ & $0.7966^{* *}$ & $0.1533^{*}$ & 0.0222 & $-0.3953 * *$ & $0.6876 * *$ \\
\hline & $\mathrm{P}$ & & & & & & 1.0000 & $0.1965 * *$ & $0.7881 * *$ & $0.1369 *$ & 0.0155 & $-0.3786 * *$ & $0.6793 * *$ \\
\hline \multirow[t]{2}{*}{ NPB } & G & & & & & & & 1.0000 & $0.1412 *$ & 0.0163 & -0.0782 & -0.0681 & 0.0949 \\
\hline & $\mathrm{P}$ & & & & & & & 1.0000 & $0.1253 *$ & 0.0183 & -0.0691 & -0.0554 & 0.0860 \\
\hline \multirow[t]{2}{*}{ NPP } & $\mathrm{G}$ & & & & & & & & 1.0000 & $0.6927 * *$ & $0.3082 * *$ & $-0.4709 * *$ & $0.9412 * *$ \\
\hline & $\mathrm{P}$ & & & & & & & & 1.0000 & $0.6861 * *$ & $0.2910 * *$ & $-0.4580 * *$ & $0.9365 * *$ \\
\hline \multirow[t]{2}{*}{ NPC } & G & & & & & & & & & 1.0000 & $0.4746 * *$ & $-0.3339 * *$ & $0.7170 * *$ \\
\hline & $\mathrm{P}$ & & & & & & & & & 1.0000 & $0.4544 * *$ & $-0.3236^{* *}$ & $0.7060 * *$ \\
\hline \multirow[t]{2}{*}{ NSP } & $\mathrm{G}$ & & & & & & & & & & 1.0000 & $-0.1963 * *$ & $0.4877 * *$ \\
\hline & $\mathrm{P}$ & & & & & & & & & & 1.0000 & $-0.1909 * *$ & $0.4755^{* *}$ \\
\hline \multirow[t]{2}{*}{ HSW } & G & & & & & & & & & & & 1.0000 & $-0.3110 * *$ \\
\hline & $\mathrm{P}$ & & & & & & & & & & & 1.0000 & $-0.2935 * *$ \\
\hline
\end{tabular}

* Significant at 5 per cent level

** Significant at 1 per cent level Phenotypic correlation coefficients
DFF - Days to $50 \%$ flowering, DTM - Days to maturity, PH - Plant height, PL - Pod length, PW - Pod width, NCP - Number of clusters per plant, NPB -

$\mathrm{G}-$ Genotypic correlation coefficients Number of primary branches, NPP - Number of pods per plant, NPC - Number of pods per cluster, NSP - Number of seeds per pod, HSW - Hundred seed weight, SPY - Single plant yield 
Table.4 Estimates of direct and indirect effects of different quantitative traits (partitioned by path analysis)

\begin{tabular}{|c|c|c|c|c|c|c|c|c|c|c|c|c|}
\hline & DFF & DTM & PH & PL & PW & NCP & NPB & NPP & NPC & NSP & HSW & SPY \\
\hline DFF & -0.3026 & -0.2987 & 0.0390 & 0.0065 & 0.0656 & -0.0097 & -0.0114 & 0.0264 & 0.0593 & 0.0376 & -0.0159 & -0.0760 \\
\hline $\begin{array}{l}\text { DT } \\
\mathbf{M}\end{array}$ & 0.3272 & 0.3314 & -0.0456 & -0.0265 & -0.0631 & -0.0061 & 0.0202 & -0.0450 & -0.0702 & -0.0488 & 0.0331 & -0.1125 \\
\hline PH & 0.0010 & 0.0010 & -0.0075 & -0.0009 & 0.0012 & -0.0022 & -0.0019 & -0.0028 & -0.0022 & -0.0004 & 0.0015 & $0.3266 * *$ \\
\hline PL & 0.0003 & 0.0011 & -0.0015 & -0.0134 & 0.0055 & -0.0037 & 0.0036 & -0.0068 & -0.0061 & -0.0085 & 0.0048 & $0.5659 * *$ \\
\hline PW & 0.0051 & 0.0044 & 0.0037 & 0.0096 & -0.0233 & 0.0028 & -0.0061 & 0.0042 & 0.0021 & 0.0004 & -0.0072 & $-0.1457 *$ \\
\hline NCP & -0.0008 & 0.0004 & -0.0071 & -0.0067 & 0.0030 & -0.0244 & -0.0053 & -0.0195 & -0.0037 & -0.0005 & 0.0097 & $0.6876 * *$ \\
\hline NPB & -0.0006 & -0.0009 & -0.0038 & 0.0041 & -0.0040 & -0.0033 & -0.0154 & -0.0022 & -0.0002 & 0.0012 & 0.0010 & 0.0949 \\
\hline NPP & -0.0877 & -0.1366 & 0.3762 & 0.5126 & -0.1824 & 0.8011 & 0.1420 & 1.0057 & 0.6967 & 0.3099 & -0.4736 & $0.9412 * *$ \\
\hline NPC & 0.0023 & 0.0024 & -0.0034 & -0.0053 & 0.0010 & -0.0018 & -0.0002 & -0.0080 & -0.0115 & -0.0055 & 0.0039 & $0.7170 * *$ \\
\hline NSP & -0.0295 & -0.0349 & 0.0131 & 0.1502 & -0.0045 & 0.0053 & -0.0185 & 0.0731 & 0.1126 & 0.2372 & -0.0465 & $0.4877 * *$ \\
\hline $\begin{array}{l}\text { HS } \\
\mathbf{W}\end{array}$ & 0.0094 & 0.0178 & -0.0364 & -0.0643 & 0.0553 & -0.0705 & -0.0122 & -0.0840 & -0.0595 & -0.0350 & 0.1783 & $-0.3110 * *$ \\
\hline
\end{tabular}

Residual effect $=0.2017$; Diagonal and bold indicates the direct effects

* Significant at 5 per cent level

** Significant at 1 per cent level

DFF - Days to $50 \%$ flowering, DTM - Days to maturity, PH - Plant height, PL - Pod length, PW - Pod width, NCP - Number of clusters per plant, NPB Number of primary branches, NPP - Number of pods per plant, NPC - Number of pods per cluster, NSP - Number of seeds per pod, HSW - Hundred seed weight, SPY - Single plant yield. 
In general, genotypic correlation was found to be higher in magnitude than phenotypic correlation. This may be due to modifying effects of environment on association of traits at genetic level (Johnson et al., 1955b). Single plant yield showed significant positive correlation with plant height $\left(r_{g}=0.3266\right.$, $\left.\mathrm{r}_{\mathrm{P}}=0.3154\right)$, pod length $\quad\left(\mathrm{r}_{\mathrm{g}}=0.5659\right.$, $\left.r_{P}=0.5332\right)$, number of clusters per plant $\left(r_{g}=0.6876, r_{P}=0.6793\right)$, number of pods per plant $\left(r_{\mathrm{g}}=0.9412, \mathrm{r}_{\mathrm{P}}=0.9365\right)$, number of pods per cluster $\left(r_{\mathrm{g}}=0.7170, \quad \mathrm{r}_{\mathrm{P}}=0.7060\right)$ and number of seeds per pod $\left(r_{\mathrm{g}}=0.4877\right.$, $\left.\mathrm{r}_{\mathrm{P}}=0.4755\right)$ at both genotypic and phenotypic level. Similar results were obtained by Manggoel et al., 2012 in cowpea accessions at genotypic level. Significant negative association with yield was observed for pod width and hundred seed weight.

Knowledge on inter correlation between quantitative traits may facilitate breeders to decide the direction of selection on related traits for improvement. Traits viz., number of cluster per plant exhibited significant positive inter-correlation with plant height, pod length, number of pods per plant and number of pods per cluster. Similarly, yield components viz., number of pods per plant and number of pods per cluster showed positive significant inter correlation with plant height, pod length and number of seeds per pod respectively. Hence, selection based on six yield components viz., number of cluster per plant, plant height, pod length, number of pods per plant, number of pods per cluster and number of seeds per pod would help to identify promising genotypes. It is suggested that the above mentioned traits shall be given importance while excising selection as it had exhibited significant direct association with yield and also proves to be promising yield contributing components.

Partitioning the genotypic correlation into direct and indirect effects by path analysis would provide idea on relative contribution of each trait and its influence through other traits on yield. The results of path analyses were presented in Table 4. Four traits viz., days to maturity (0.3314), number of pods per plant (1.0057), number of seeds per pod (0.2372) and hundred seed weight $(0.1783)$ recorded positive and high direct effects on single plant yield. The results were in accordance with Reddy et al., (2011) in greengram and Praveen et al., (2011) in blackgram. Yield attributing characters like plant height, pod length, number of cluster per plant, number of pods per cluster and number of seeds per pod exhibited positive and high indirect effects on yield through number of pods per plant. Hundred seed weight exhibited positive and high direct effect but negatively correlated with yield. Hence, direct selection for the trait should be employed to remove the undesirable indirect effects. The residual effect (0.2017) is low which indicates the larger contribution of traits towards variability specifically with respect to yield. From correlation and path analysis, it is concluded that adopting selection techniques for the traits viz., number of cluster per plant, plant height, pod length, number of pods per plant, number of pods per cluster and number of seeds per pod would be more rewarding in bringing yield improvement in horsegram since they were considered as major yield contributing traits.

\section{Acknowledgements}

We acknowledge sincerely the Board of Research in Nuclear Sciences for providing the financial support and Dr. S. Dutta, Program Officer (RTAC), BARC and Dr. J. Souframanien, Principal Collaborator, NA\&BTD, BARC, Mumbai for their technical assistance towards this study. Authors express their sincere thanks to Dr. P. Jayamani, Professor and Head, Department of Pulses, TNAU, Coimbatore for her relentless scientific support. 


\section{References}

Alle, R., V. Hemalatha, K. B. Eswari, and Sivasankar, A. 2015. Genetic Variability, Heritability and Genetic Advance of Yield and Its Components in Horsegram (Macrotyloma uniflorum [Lam.] Verdc.). Environment \& Ecology. 33(4C):2019-2021.

Babu, V.R., K. Shreya, K.S. Dangi, G. Usharani, and Nagesh, P. 2012. Genetic variability studies for qualitative and quantitative traits in popular rice (Oryza sativa L.) hybrids of India. International Journal of Scientific and Research Publications. 2(6):1-5.

Burton, G.W. 1952. Quantitative inheritance in grass. Proceedings of 6 th International grassland Congress. 01, 24-83.

Dewey, D.R., and Lu, K.H. 1959. A correlation and path coefficient analysis of components of crested wheat grass seed production. Agronomy Journal. 51, 515-518.

Johnson, H.W., H.F. Robinson, and Comstock, R.E. 1955a. Estimates of genetic and environment variability in soybean. Agronomy Journal. 47, 314318.

Johnson, H.W., H.F. Robinson, and Comstock, R.E. 1955b. Genotypic and phenotypic correlation in soybean and their implications in selection. Agronomy Journal. 47, 477-485.

Joshi, P., M. Yasin, and Sundaram, P. 2018. Genetic Variability, Heritability and Genetic Advance Study for Seed Yield and Yield Component Traits in a Chickpea Recombinant Inbred Line (RIL) Population. Int. J. Pure App. Biosci. 6(2):136-141.

Kumar, N., V.N. Joshi, and Dagla, M.C. 2013. Multivariate analysis for yield and its component traits in maize (Zea mays L.) under high and low $\mathrm{N}$ levels.
The Bioscan. 8(3):959-964.

Latha, M., A. Suma, K.I. Asha, N.K. Dwivedi, S. Mani, and Indiradevi, A. 2013. Seed polymorphism in south Indian horsegram (Macrotyloma uniflorum (lam.) Verdc.): a comprehensive study. Journal of applied biology and biotechnology. 1(4):1-6.

Lush, J.L. 1940. Intra-sire correlations and regression of offspring on dams as a method of estimating heritability of characters. Proceedings of American Society of Animal Production. 33, 293301.

Manggoel, W., M.I. Uguru, O.N. Ndam, and Dasbak, M.A. 2012. Genetic variability, correlation and path coefficient analysis of some yield components of ten cowpea [Vigna unguiculata (L.) Walp] accessions. Journal of Plant Breeding and Crop Science. 4(5):80-86.

Narmada Varma, P., B. Baisakh, and Swain, D. 2018. Study on Genetic Variability, Correlation and Path Coefficient Analysis for Yield and Component Traits in Greengram. Int. J. Curr. Microbiol. App. Sci. 7(10): 3429-3436.

Parveen, S.I., M.R. Sekhar, D.M. Reddy, and Sudhakar, P. 2011. Correlation and path coefficient analysis for yield and yield components in blackgram (Vigna mungo (L.) Hepper). International Journal of Applied Biology and Pharmaceutical Technology. 2(3):619625.

Rakesh Gandi, N., Shunmugavalli, and Muthuswamy. 2018. Genetic Variability, Heritability and Genetic Advance Analysis in Segregating Population of Black Gram [Vigna mungo (L.) Hepper]. Int. J. Curr. Microbiol. App. Sci. 7(2):703-709.

Reddy, D., O. Venkateswarlu, M.C. Obaiah, and Jyothi, G.L. 2011. Heterosis for yield and yield components in greengram [Vigna radiata (L.) 
Wilczek]. Legume Research. 34(3):207211.

Singh, R.K., and Chaudhary, B.D. 1977. Biometrical methods in quantitative genetic analysis. Kalyani Publishers. New Delhi, Ludhiana.

Sivasubramanian, S., and Menon, P.M. 1973. Genotypic and phenotypic variability in rice. Madras Agricultural Journal. 60(9-
13):1093-1096.

Vijayakumar, A., S. Koraddi, I.H. Boodi, and Kallesh, D. 2016. Genetic variability studies in horse gram [Macrotyloma uniflorum (lam.) Verdc.]. The Bioscan. 11(2): 1255-1259.

Yadav, S. 2004. Protein and oil rich wild horsegram. Genetic Resources and Crop Evolution. 51:629-633.

\section{How to cite this article:}

Priyanka, S., R. Sudhagar, C. Vanniarajan and Ganesamurthy, K. 2019. Investigation on Genetic Variability Parameters and Association of Traits in Horsegram (Macrotyloma uniflorum (Lam) Verdc.). Int.J.Curr.Microbiol.App.Sci. 8(02): 656-664. doi: https://doi.org/10.20546/ijcmas.2019.802.074 